\title{
RECENT GLACIER ADVANCES IN NORWAY AND NEW ZEALAND: A COMPARISON OF THEIR GLACIOLOGICAL AND METEOROLOGICAL CAUSES
}

\author{
BY \\ T. CHINN ${ }^{1}$, S. WINKLER ${ }^{2}$, M.J. SALINGER ${ }^{3}$ AND N. HAAKENSEN $^{4}$ \\ ${ }^{1}$ Lake Hawea, Wanaka, Otago, New Zealand \\ 2 Department of Geography, University of Würzburg, Würzburg, Germany \\ ${ }^{3}$ National Institute of Water and Atmospheric Research, Auckland, New Zealand \\ ${ }^{4}$ Norwegian Water Resources and Energy Directorate (NVE), Oslo, Norway
}

Chinn, T., Winkler, S., Salinger, M.J. and Haakensen, N., 2005: Recent glacier advances in Norway and New Zealand: a comparison of their glaciological and meteorological causes. Geogr. Ann., 87 A (1): 141-157.

ABSTRACT. Norway and New Zealand both experienced recent glacial advances, commencing in the early 1980s and ceasing around 2000, which were more extensive than any other since the end of the Little Ice Age. Common to both countries, the positive glacier balances are associated with an increase in the strength of westerly atmospheric circulation which brought increased precipitation. In Norway, the changes are also associated with lower ablation season temperatures. In New Zealand, where the positive balances were distributed uniformly throughout the Southern Alps, the period of increased mass balance was coincident with a change in the Interdecadal Pacific Oscillation and an associated increase in EI Niño/Southern Oscillation events. In Norway, the positive balances occurred across a strong west-east gradient with no balance increases to the continental glaciers of Scandinavia. The Norwegian advances are linked to strongly positive North Atlantic Oscillation events which caused an overall increase of precipitation in the winter accumulation season and a general shift of maximum precipitation from autumn towards winter. These cases both show the influence of atmospheric circulation on maritime glaciers.

Key words: glaciers, mass balance, advance, NAO, IPO, ENSO/ SOI, Norway, New Zealand

\section{Introduction}

During the 20th century, worldwide glacier recession following the 19th century maximum of the Little Ice Age (LIA) (Grove 1988) has continued, being interrupted by only minor readvances of various glaciers at many different locations (IPCC 2001). The mass loss is evident as retreating front positions and is predicted to continue into the future (Haeberli et al. 1999). However, glaciers in two widely separated regions have recently shown the opposite behaviour towards the end of the 20th century. In maritime western Scandinavia, excluding the northernmost glaciers of Norway, most glaciers have experienced strong advances during the past two decades (Winkler et al. 1997). Similar recent glacier advances following two decades of positive glacier mass balances have also occurred in the Southern Alps of New Zealand (Chinn 1999). Iceland is among the few other regions where positive glacier mass balances have been reported in the same period (Dowdeswell et al. 1997).

The simultaneous period of mass gain to the glaciers in both Norway and New Zealand is examined here to identify common causes. This is important for understanding the nature of glacier response to climate variability and its circulation. Glaciers are amongst the most sensitive 'instruments' indicating climate change, especially regional warming trends (IPCC 2001), the changes being very obvious as changes in glacier mass, area and frontal positions. However, interpreting the climate phenomena responsible for those changes remains a complex problem. One of the aims of this paper is to attempt to identify some of the common climatic factors responsible for these glacier mass changes.

\section{The study areas and their glaciers \\ Norway}

Norway extends from $c .58^{\circ} \mathrm{N}$ to over $71^{\circ} \mathrm{N}$ with mountains that rise to a maximum of nearly 2500 $\mathrm{m}$ a.s.l. and support substantial glaciation in several different regions (Fig. 1). A total of 1627 individual glaciers is recorded for Norway, with 714 of those 


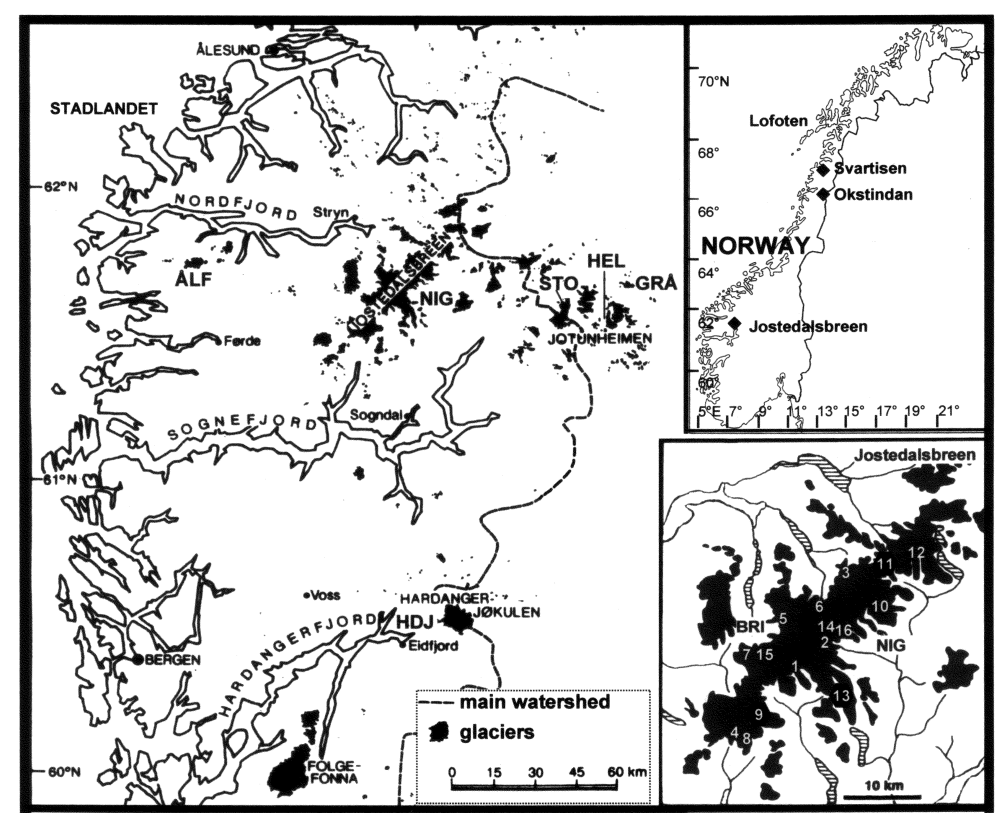

Fig. 1. Location map of the glaciers of Norway. Glaciers mentioned in Figs 3 and 4 are indicated by abbreviations: $\AA \mathrm{ALF}=$ Ålfotbreen, BRI = Brigsdalsbreen, GR $\AA$ = Gråsubreen, $\mathrm{HDJ}=$ Hardangerjøkulen, $\mathrm{HEL}=$ Hellstugubreen, NIG $=$ Nigardsbreen, STO = Storbreen. Insert shows Jostedalsbreen with numbers for the outlet glaciers named in Tables 1 and 3 in southern Norway (Østrem et al. 1973, 1988). The glacierized area of Norway is $c .2609 \mathrm{~km}^{2}$, with $1592 \mathrm{~km}^{2}$ in southern Norway.

Norway is exposed to maritime humid airflow of the North Atlantic westerlies. Annual precipitation ranges from $3500 \mathrm{~mm}$ at the foot of coastal mountain regions (Førland 1993) to over $5000 \mathrm{~mm}$ in the higher mountains. Frequent southwesterly airflow in combination with the warm North Atlantic Current causes a positive temperature anomaly along the Norwegian coast with comparatively mild winter temperatures. The SW-NE orientation of the mountain ranges parallel to the coast creates a pronounced maritime-continental precipitation gradient across Scandinavia with precipitation decreasing dramatically eastward of the main divide. Significant behavioural differences exist between the western (maritime) and eastern (more continental influenced) glaciers (Winkler et al. 1997; Winkler and Haakensen 1999).

Maritime Norway typically has large plateau glaciers with several distributory outlets descending well down into the surrounding valleys, e.g. Jostedalsbreen $\left(487 \mathrm{~km}^{2}\right)$, Svartisen (two areas, totalling $369 \mathrm{~km}^{2}$ ) and Folgefonna (three areas, in total $219 \mathrm{~km}^{2}$ ). In other regions with Alpine-type morphology, smaller valley and cirque glaciers dominate (e.g. Jotunheimen, Lyngshalvøya). Apart from a few small high-lying cirque glaciers in the highest and more continental parts of southern Norway (Jotunheimen) and thin ice plateaux in the far north, all Norwegian glaciers are believed to be temperate/warm-based. The wide variety of glacier types means that that glacier reaction times to mass balance gains have to be taken into account when interpreting glacier fluctuations.

\section{New Zealand}

In the Southern Alps of New Zealand, average summit heights range from $1850 \mathrm{~m}$ in Fiordland to $3000 \mathrm{~m}$ in the central Alps and descend to $2000 \mathrm{~m}$ in the north. The 3144 inventoried glaciers covering $1158 \mathrm{~km}^{2}$ are distributed from the Inland Kaikoura Range at $42^{\circ} 01$ 'S in the north, to southern Fiordland at $45^{\circ} 57$ 'S in the south (Fig. 2) and contain an estimated $53.29 \mathrm{~km}^{3}$ of ice (Chinn 2001).

New Zealand also has a humid maritime climate with the Southern Alps lying across the path of the prevailing southern westerly wind belt, a situation similar to Norway, which creates steep eastward precipitation gradients with strong föhn effects in westerly conditions. Mean annual precipitation rises rapidly from $3000 \mathrm{~mm}$ along the narrow western coastal plain to a maximum of over $10000 \mathrm{~mm}$ in areas immediately west of the Main Divide (Grif- 
Fig. 2. Distribution of the glaciers of the New Zealand Southern Alps with open circles indicating the 'index' glaciers providing surrogate mass balance data

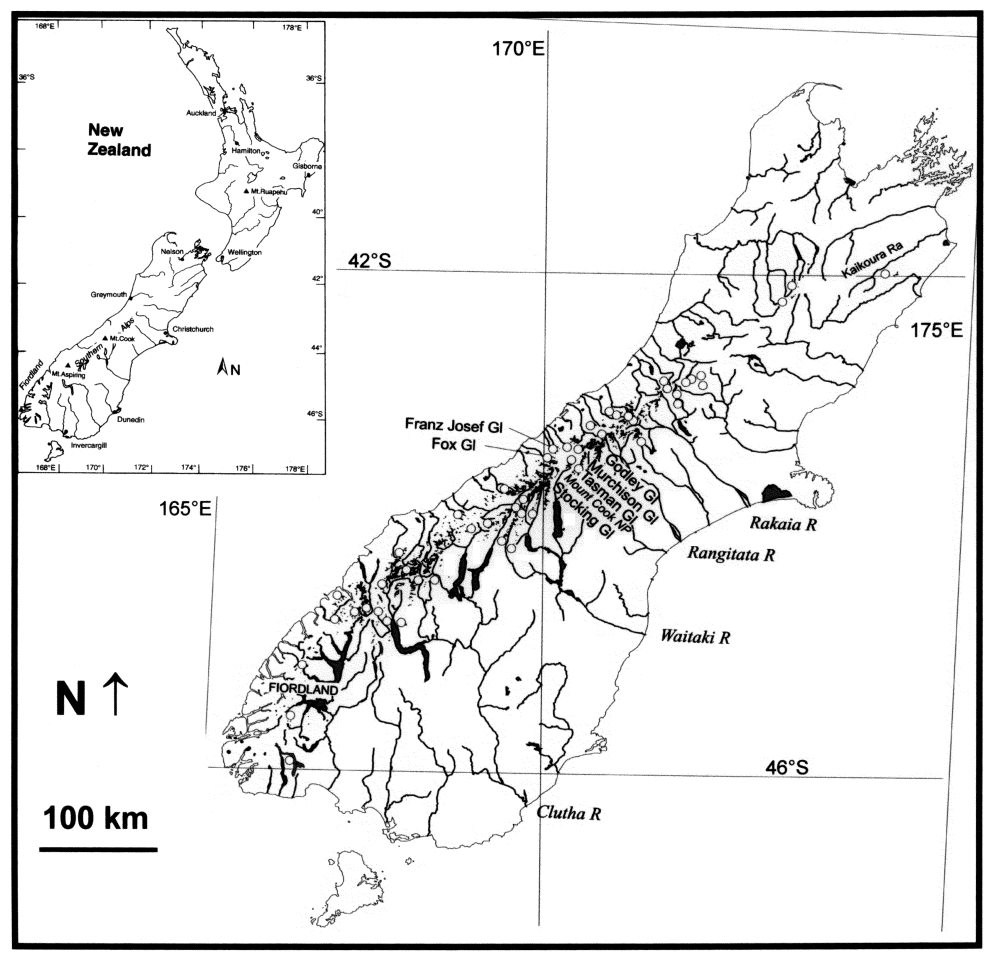

fiths and McSaveney 1983). Precipitation is evenly distributed throughout the year.

New Zealand has numerous cirque and alpine glaciers, whilst the central Southern Alps, where summit heights reach well above the regional snowline, contain large valley glaciers which are renowned for their extensive areas of supraglacial debris cover on the lower tongues. Many of these large debris-mantled valley glaciers have recently entered a period of rapid retreat by accelerating proglacial lake growth.

\section{Holocene glacier changes Norway}

Almost all glaciers in Norway experienced their Holocene maxima during the Little Ice Age (LIA) (Bogen et al. 1989). The majority of the glaciers probably disappeared during the Middle Holocene and re-established during the Late Holocene (Matthews and Shakesby 1984; Nesje et al. 1991). Only some high-lying cirque glaciers in more continental mountain regions (e.g. Jotunheimen) might have survived throughout the entire Holocene.
However, in northern Norway there are few glaciers with pre- LIA moraines formed during the Late Holocene (Griffey and Worsley 1978; Ballantyne 1990; Winkler 2003).

The LIA maxima at the outlets of Jostedalsbreen, a maritime plateau glacier in western south Norway (Fig. 1), can be dated to the mid-18th century (Fægri 1934; Bogen et al. 1989; Bickerton and Matthews 1993). In the more continental mountain area of Jotunheimen, a double main advance with spatially separated peaks around AD 1750 and 1800 is reported (Erikstad and Sollid 1986; J.A. Matthews pers. comm.). Earlier advances dating back to the 16th and 17th centuries have been reported from northern Norway and northern Sweden (Karlén 1979), while new results from Svartisen and Okstindan in northern Norway $\left(c .66-67^{\circ} \mathrm{N}\right)$ show a synchronous LIA maximum around the middle of the 18th century (Winkler 2003). Exceptions are the northernmost glacier regions such as Lyngen Peninsula (Fig. 1) which have a LIA maximum in the early 19th century or later (Ballantyne 1990; Winkler 2001), as do Folgefonna in southern Norway with a later main advance leading to LIA maxi- 
Table 1. Terminus changes at some outlets of Jostedalsbreen. Timing and distance gained of two readvances during the first part of the 20th century and successive loss during the major retreat period of the middle of the 20th century (data sources: Fægri 1948; Winkler 1996; Norges Vassdrags- og Energidirektoratet (NVE)). The glaciers are grouped into outlets with short terminus response times (nos. 1-9) and larger outlets with longer terminus response time (nos. 10-13). In contrast to the recent advance, these two earlier readvances were restricted mainly to the steep outlet glaciers

\begin{tabular}{|c|c|c|c|c|c|c|c|}
\hline Glacier $^{(a)}$ & $\begin{array}{l}\text { Advance } \\
\text { period }\end{array}$ & $\begin{array}{l}\text { Distance } \\
(\mathrm{m})\end{array}$ & Advance & $\begin{array}{l}\text { Distance } \\
(\mathrm{m})\end{array}$ & $\begin{array}{l}\text { Retreat } \\
\text { period }\end{array}$ & $\begin{array}{l}\text { Distance } \\
(\mathrm{m})\end{array}$ & $\begin{array}{l}\text { Max. annual } \\
\text { retreat } \\
\text { (m) }\end{array}$ \\
\hline (1) Austerdalsbreen & *1905-09 & 63 & no data ${ }^{(\mathrm{c})}$ & & $\begin{array}{r}* 1933-73 \\
1973-89\end{array}$ & $\begin{array}{l}-1290 \\
-82\end{array}$ & $-187(1941 / 42)$ \\
\hline (2) Bergsetbreen & $* 1903-10$ & 135 & $1922-31$ & 127 & $1931-45 \dagger$ & -564 & $-66(1941 / 42)$ \\
\hline (3) Bødalsbreen & $* 1900-12$ & 48 & $1922-30$ & 62 & $1930-53 \dagger$ & -712 & - $104(1942 / 43)$ \\
\hline (4) Bøyabreen & $* 1904-11$ & 134 & $1921-31$ & 164 & $1931-52$ & -604 & $-115(1942 / 43)$ \\
\hline (5) Brenndalsbreen & $1905-13$ & 96 & $1922-32$ & 73 & $1932-57$ & -1332 & $-254(1945 / 46)$ \\
\hline Brigsdalsbreen & $1904-10$ & 78 & $1921-31$ & 67 & $1931-55$ & -866 & $-79(1947 / 48)$ \\
\hline (6) Kjenndalsbreen & *1907-09 & 44 & $1922-32$ & 191 & $1932-52 \dagger$ & -1546 & $-314(1943 / 44)$ \\
\hline (7) Melkevollbreen & $1902-11$ & 177 & 1933-39 & 208 & $1929-41 \dagger$ & -689 & $-203(1938 / 39)$ \\
\hline (8) Supphellebreen & *1899-1912 & 96 & $1921-31$ & 92 & $1931-57$ & -303 & $-37(1934 / 35)$ \\
\hline (9) V.Supphellebre & $1902-11$ & 148 & $1922-31$ & 115 & $1931-44 \dagger$ & -557 & $-200(1941-43)^{(\mathrm{d})}$ \\
\hline (10) Fåbergstølsbreen & $* 1907-10$ & 25 & $1922-30$ & 113 & $1930-92$ & -2433 & $-138(1965 / 66)$ \\
\hline (11) Lodalsbreen & no advance & & $1925-29$ & $-5^{(b)}$ & $1932-70 \dagger$ & -1741 & - $145(1965 / 66)$ \\
\hline Nigardsbreen & $* 1903-11$ & $-9^{(b)}$ & $1921-30$ & 19 & $\begin{array}{l}1931-78 \\
1978-88\end{array}$ & $\begin{array}{l}-2282 \\
-29\end{array}$ & not applicable ${ }^{(\mathrm{e})}$ \\
\hline $\begin{array}{l}\text { (12) Stegholtbreen } \\
\text { (13) Tunsbergdalsbreen }\end{array}$ & $\begin{array}{l}* 1903-11 \\
\text { no advance }\end{array}$ & 36 & $\begin{array}{l}1922-32 \\
\text { no advance }\end{array}$ & 45 & $\begin{array}{l}1932-85 \\
* 1900-1957 \dagger\end{array}$ & $\begin{array}{l}-1646 \\
-913\end{array}$ & $\begin{array}{l}-116(1969 / 70) \\
\text { not applicable }^{(\mathrm{f})}\end{array}$ \\
\hline
\end{tabular}

$*$ precise year of onset unknown; $\dagger$ measurements ceased.

a) Locations given by numbers on Jostedalsbreen map insert in Fig. 1.

b) Individual years of retreat give an overall retreat during the 'readvance' period.

c) Although no precise data are available, this glacier also advanced (Winkler 1996).

d) Distance given for two-year period.

e) Due to calving into a proglacial lake.

f) Due to comparative early end of measurements.

ma as late as the last decades of the 19th century or the early 20th century (Tvede and Liestøl 1977; Bogen et al. 1989).

The retreat from the LIA maximum positions occurred more or less continuously both in southern and in northern Norway, but it was slow and frequently interrupted by short still-stands and some minor readvances. At the outlets of Jostedalsbreen, two readvances during the first decades of the 20th century were studied in detail (Table 1; Bogen et al. 1989; Winkler 1996). In Jotunheimen there was a readvance around 1920 (Hoel and Werenskiold 1962). However, in all glacier regions in Norway, the middle of the 20th century was characterized by considerable and fast glacier retreat (Table 1; Fægri 1948).

\section{New Zealand}

The record of Holocene Neoglacial activity in New Zealand commenced around c. 5000 years BP (Por- ter 2000). In contrast to Norway, early and midNeoglacial moraines were not usually overridden by the late Neoglacial or LIA expansions allowing progressively smaller and younger advances to create nested moraine sequences recording most of the Neoglacial events (e.g. Grove 1988; Gellatly et al. 1988; Röthlisberger 1986). Recent glacial morphological evidence (Winkler in press), however, does suggest that the number of major Neoglacial advances is fewer than indicated in the literature.

There are numerous records of late Neoglacial frontal positions since the 14th century (Gellatly 1985; Wardle 1973; Röthlisberger 1986). Dated moraines indicate that LIA maxima were reached by different glaciers at widely different times depending on their response times and glacier morphology. Terminus response times to increased mass balance vary from about 5 years for the steep reactive glaciers, to in the order of a century for the large, low-gradient valley glaciers (Oerlemans 1989; Haeberli and Hoelzle 1995). Response time 
Fig. 3. Cumulative glacier front variations of Brigsdalsbreen (BRI), a steep, short outlet glacier of Jostedalsbreen with an observed terminus response time of $c .4$ years, Nigardsbreen (NIG), a long outlet glacier (terminus response time $c$. 25 years), and Hellstugubreen (HEL), a valley glacier in the continental Jotunheimen (data source: NVE)

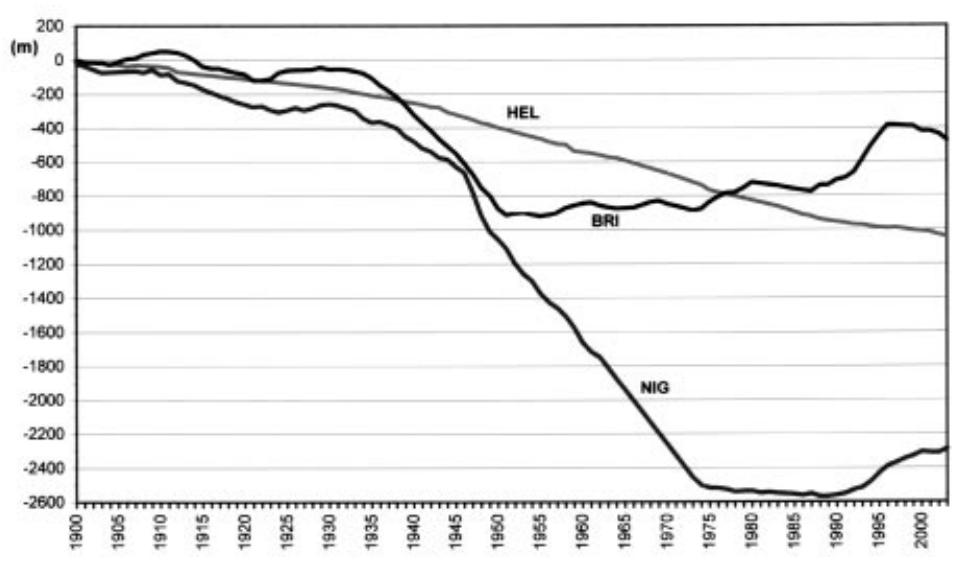

variations are evident in the wide variety of dates which indicate that the LIA maximum was attained by some glaciers as early as AD 1600 (Wardle 1973; Gellatly et al. 1988). Later maxima (or readvances) have been dated at the mid- to late 1700 s, early to the mid-1800s, and late 1900s. Recent datings of the LIA maximum in Mt. Cook National Park (Winkler 2004) suggest the maximum glacier expansion during the middle of the 18th century was contemporaneous with advances of Franz Josef and Fox Glaciers (Lawrence and Lawrence 1965; Anderson 2003). At these glaciers, retreat between $c$. 1750 and the first decades of the 20th century was only minor. Readvances were reported by the first scientific explorers and surveyors around c. 1860 and in 1900 most glaciers were still very close to their LIA maximum positions (cf. Gellatly 1985; Chinn 1996). Glacier positions remained relatively unchanged during the first three decades of the 20th century with a major frontal retreat not starting be- fore $c .1930$ at most of the major glaciers of the Southern Alps (Table 2; Gellatly 1985; Kirkbride 1993).

\section{Recent glacier advance and mass balance changes \\ Norway}

At the short and steep outlets of Jostedalsbreen, the main retreat ended during the late 1950s to early 1960s. These glaciers have a relatively short terminus response or lag time (Paterson 1994) of around 3-4 years. After some years with more or less stationary glacier front positions, they began to advance, accelerating in the late 1980s (Fig. 3). Due to their longer response time, the larger outlets of Jostedalsbreen (Nesje 1989; Winkler 1996) did not start advancing before around the late 1980s to early 1990s (Fig. 3). During the 1990s all outlets of Jostedalsbreen were advancing. Around 2000 the

Table 2. Retreat of New Zealand glaciers from the Little Ice Age maximum position to 1978. Samples (number in brackets) of cirque, mountain and valley glaciers including valley glaciers with proglacial lakes (after Chinn 1996)

\begin{tabular}{|c|c|c|c|c|c|}
\hline Glacier type $^{(a)}$ & $\begin{array}{c}\text { Area loss }^{(\mathrm{b})} \\
(\%)\end{array}$ & $\begin{array}{l}\text { Mean ELA } \\
\text { rise }(\mathrm{m})\end{array}$ & $\begin{array}{l}\text { Length loss } \\
(\mathrm{km})\end{array}$ & $\begin{array}{c}\text { Length loss } \\
(\%)\end{array}$ & $\begin{array}{c}\text { Retreat rate } \\
\left(\mathrm{ma}^{-1}\right)\end{array}$ \\
\hline Cirque (26) & - & 83.6 & 0.78 & 48 & 7.8 \\
\hline Alpine (51) & $32(5)$ & 137 & 1.17 & 44 & 11.7 \\
\hline Valley (34) & $24.6(11)$ & 68 & 1.77 & 29 & 17.7 \\
\hline Valley with lake ${ }^{(\mathrm{c})}(16)$ & $23(9)$ & 16 & 1.82 & 24 & 18.2 \\
\hline
\end{tabular}

a) Classification of glaciers following Chinn (1996); the number of glaciers measured is given in brackets, with column 2 numbers given separately.

b) Area loss calculated for fewer glaciers with number given in brackets.

c) Special conditions; see text. 

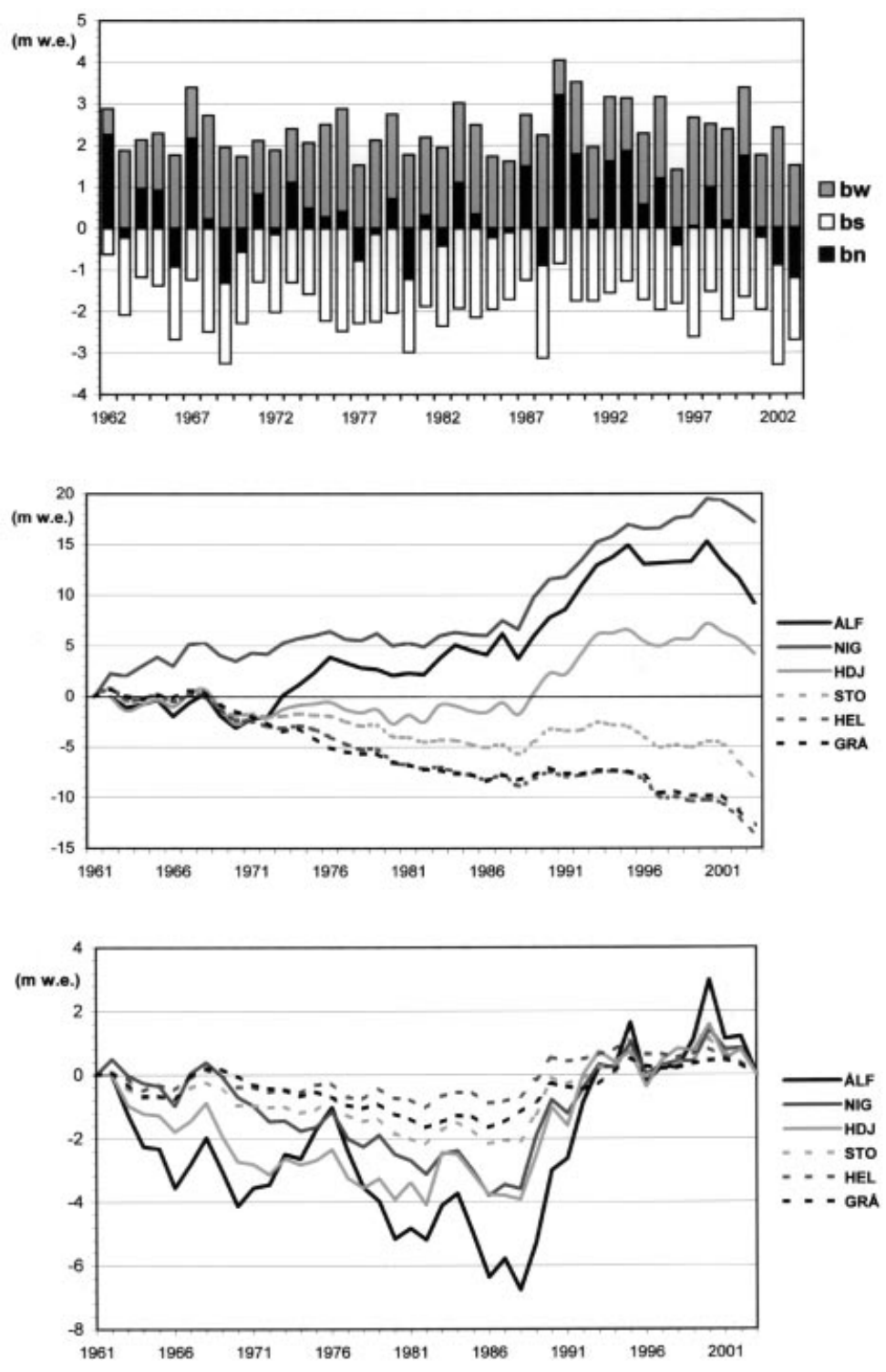

Fig. 4. Upper panel: annual mass balance data for Nigardsbreen, showing the dominance of positive net balance years, $b n=$ net annual balance, $\mathrm{bs}=$ summer balance and bw = winter balance. Centre panel: cumulative net balances of six glaciers located on a W-E profile through western south Norway (see Fig. 1). Lower panel: cumulative deviations from the average winter balance for those six glaciers. Although total values of winter balances are highest at the maritime Ålfotbreen and much lower at the continental Gråsubreen, the annual trends are conformable (data source: NVE)

advances of some of the short and steep outlets ceased. This was probably due to the negative mass balance of 1996, an equilibrium mass balance for 1997 followed by a couple of warm summers, especially from 2000 to 2003 , causing increased ablation and mass loss at the lower tongues. Most of the larger outlets with longer reaction times are continuing to advance. The distances regained and the duration of this recent advance episode (Table 3 ) are both far greater than any previous readvance since the LIA maximum, making the recent resurgence a significant event (Winkler et al. 1997). This phase of glacier expansion is confined to the maritime glacier regions of southern Norway and northward towards the Svartisen area (Kjøllmoen 2000). The glaciers in Jotunheimen, for example, are still in retreat, although retreat rates of some glaciers here have recently slowed.

Annual mass balance data are available from the early 1960 s for six glaciers located on a W-E pro- 
Table 3. Duration and distances of the recent glacier advances at some outlets of Jostedalsbreen in western South Norway (data sources: Konnestad Sorteberg 1998; Winkler 2001; NVE)

\begin{tabular}{|c|c|c|c|c|}
\hline Glacier $^{(a)}$ & Advance period $^{(\mathrm{b})}$ & $\begin{array}{l}\text { Distance } \\
(\mathrm{m})\end{array}$ & $\begin{array}{l}\text { Length of glacier }{ }^{(\mathrm{d})} \\
\qquad(\mathrm{km})\end{array}$ & $\begin{array}{c}\text { Area } \\
\left(\mathrm{km}^{2}\right)\end{array}$ \\
\hline (14) Baklibreen & $\begin{array}{r}1964-1997 \\
(1984-1997\end{array}$ & $\begin{array}{l}+420 \\
+350)\end{array}$ & 3.5 & 3.19 \\
\hline (2) Bergsetbreen & $\begin{array}{r}1964-1997 \\
(1984-1997\end{array}$ & $\begin{array}{l}+660 \\
+360)\end{array}$ & 4.8 & 10.5 \\
\hline (3) Bødalsbreen & $1966-2000$ & +365 & 6.5 & 8.22 \\
\hline (5) Brenndalsbreen & $1986-2000$ & +200 & 2.3 & 0.88 \\
\hline Brigsdalsbreen & $\begin{array}{r}1955-1999 \\
(1987-1996\end{array}$ & $\begin{array}{l}+556^{(\mathrm{c})} \\
\left.+421^{(\mathrm{c})}\right)\end{array}$ & 6.0 & 11.94 \\
\hline (7) Kjenndalsbreen & 1964-1999 & +925 & 6.9 & 19.06 \\
\hline (15) Kjøtabreen & 1964-1999 & +260 & 3.5 & 7.44 \\
\hline (8) Melkevollbreen & $\begin{array}{r}1964-1997 \\
(1986-1997\end{array}$ & $\begin{array}{l}+770 \\
+600)\end{array}$ & 4.3 & 4.94 \\
\hline Nigardsbreen & 1988-2000 & $+267^{(\mathrm{c})}$ & 9.6 & 48.2 \\
\hline (16) Tuftebreen & 1984-1997 & +190 & 6.5 & 6.59 \\
\hline
\end{tabular}

a) Numbers correspond to Jostedalsbreen map insert in Fig. 1.

b) Data for frontal position changes derived from air photo analysis and from comparison of topographic maps.

c) Annual field measurements.

d) In 1984 (data source: Østrem et al. 1988).

file across southern Norway. These data show an increase of the glacier mass of the western glaciers (Ålfotbreen, Nigardsbreen), especially since 1988 (Fig. 4). Conversely the glaciers of Jotunheimen (Storbreen, Hellstugubreen, Gråsubreen) experienced a mass loss during the same period. The increase in glacier mass occurred at all maritime glaciers in both southern and northern Norway and south of the Svartisen area (Kjøllmoen 2000) and as a consequence of this mass gain, glaciers in the maritime regions of Norway were advancing prior to 2000 . The overall ice mass loss in eastern Jotunheimen indicates that the advances are restricted to the western maritime glaciers only.

At the maritime Alfotbreen, the mean annual winter accumulation (winter balance) is nearly five times that of the easternmost continental Gråsubreen. Because of the high precipitation and mass turnover at maritime glaciers, net balances correlate more strongly with winter balances than summer balances. Conversely, at continental glaciers net balances correlate most strongly with summer balances (Laumann and Reeh 1993; Winkler et al. 1997; Nesje et al. 2000). This suggests that frequent above-average winter balances are a main cause of the positive net balances at the maritime glaciers during the last few decades (Fig. 4). There are no visible spatial variations in the trend of winter balances when maritime and continental glaciers are compared, as all deviations from the mean winter balance occur in-phase and are, to some extent, proportional (Fig. 4), i.e. years of high winter balance usually occur on both maritime and continental glaciers. The difference in net balances may, therefore, be explained by the importance of the summer balance or conditions during the ablation season, for the continental glaciers. Radiation is more important for ablation at continental glaciers. High winter accumulation lowers the snow line and greater areas of the glacier are snow-covered in summer, lowering the albedo significantly and reducing melt rates. Due to a much lower mass turnover in Jotunheimen, the mass balance regime of these continental glaciers is more sensitive to summer temperature. The accumulation areas of Jotunheimen glaciers also 'benefit' from frequent summer snowfall events that lead to increased albedo, unlike the majority of the maritime glaciers (e.g. Allfotbreen) due to their lower altitudes. However, there are exceptions such as Nigardsbreen (an outlet glacier of Jostedalsbreen) which has accumulation areas at high altitude. This explains why Nigardsbreen currently shows the most positive net balance in Norway.

\section{New Zealand}

Along with glaciers worldwide, New Zealand glaciers have experienced large recession over the past century. Retreat commenced slowly at the begin- 

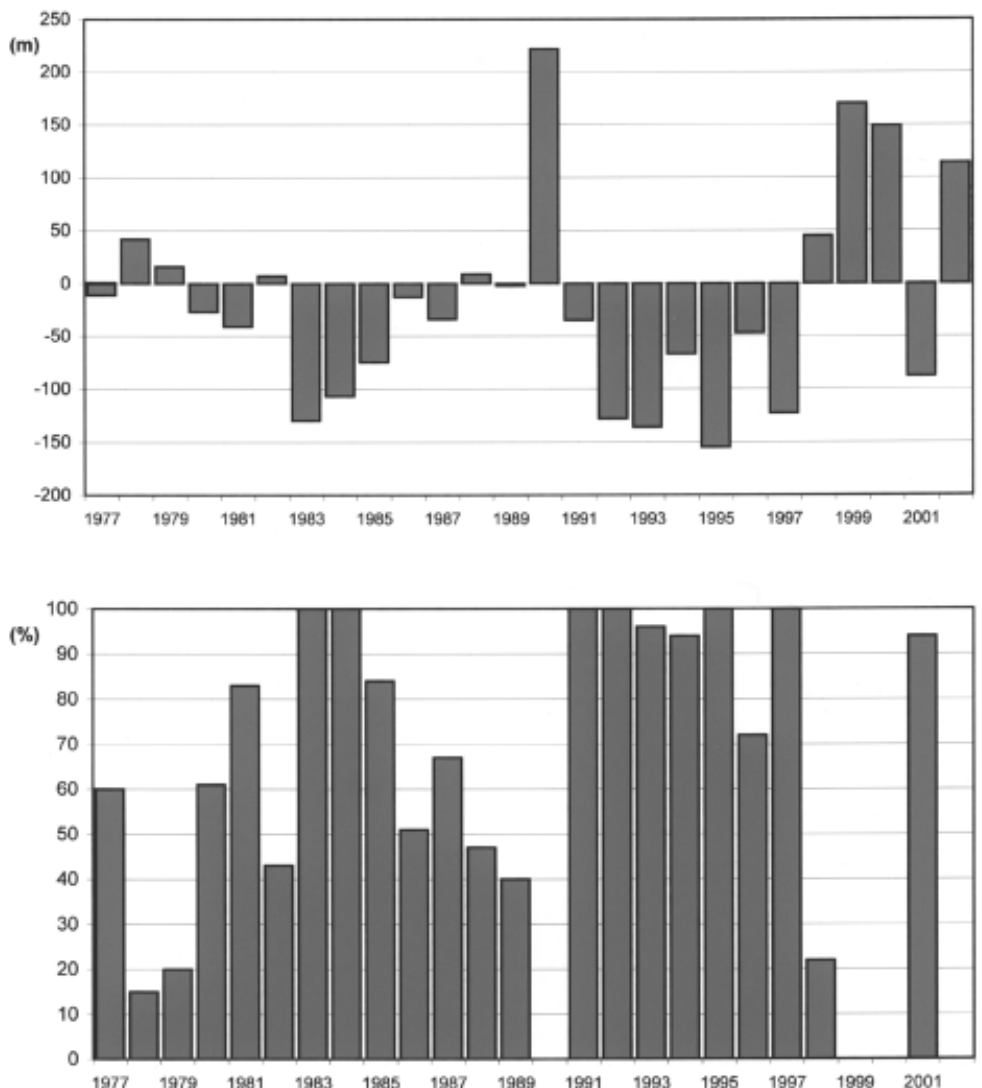

Fig. 5. Upper panel: record of mean annual end-of-summer snowline elevations (ELAs) for the New Zealand index glaciers. Negative departures or low ELAs indicate positive mass balances. Lower panel: Percentage of those index glaciers measured each year having positive mass balances as indicated by ELAs

ning of the 20th century and was greatest in the 1950s. For the more reactive glaciers with short response times, this general retreat has been punctuated by intermittent readvances. The most complete record of frontal fluctuations is for the exceptionally responsive Franz Josef Glacier where four minor readvances have been recorded. Throughout the Southern Alps, cirque and alpine glaciers have lost nearly half of their LIA lengths, whereas the valley glaciers have lost only a quarter of their original lengths. This difference is largely due to the significantly longer response times of the larger, lower gradient glaciers. Associated with retreat there has been a loss of $23 \%$ to $32 \%$ of glacierized area (Chinn 1996). Conversely, some of the debrismantled glaciers, after a century of surface lowering, still retain their Little Ice Age lengths and areas. The large proportions of debris cover on these valley glaciers has also retarded their response to warming. Many of these large valley glaciers have entered a period of rapid retreat by accelerating proglacial lake growth as an inevitable size readjustment to achieve equilibrium with the present climate.

The only significant series of direct mass balance measurements available for the Southern Alps was made at Ivory Glacier, a small $0.8 \mathrm{~km}^{2}$ cirque glacier to the west of the Main Divide, from 1969 to 1975 (Anderton and Chinn 1978). Net balances were strongly negative during the period of study. At a similar time, from 1965 to 1975 , specific balance measurements were carried out along the flow-line of the Tasman Glacier, but because of the large size of this glacier $\left(98.3 \mathrm{~km}^{2}\right)$, these values were not area-integrated to give mass balance volumes. This study has also provided useful ELA values from 1958 for this glacier.

In lieu of mass balance measurements, New Zealand has an ongoing programme which records the annual equilibrium line altitude (ELA) values from 50 selected 'index' glaciers spread throughout the length and width of the Southern Alps (Fig. 
Fig. 6. Cumulative plot of annual average 'mass balance indices' for the New Zealand Southern Alps obtained from the ELA surveys, together with the longer Tasman Glacier record of cumulative mass balance indices. Concurrent fluctuations of the length of Franz Josef Glacier are given for comparison

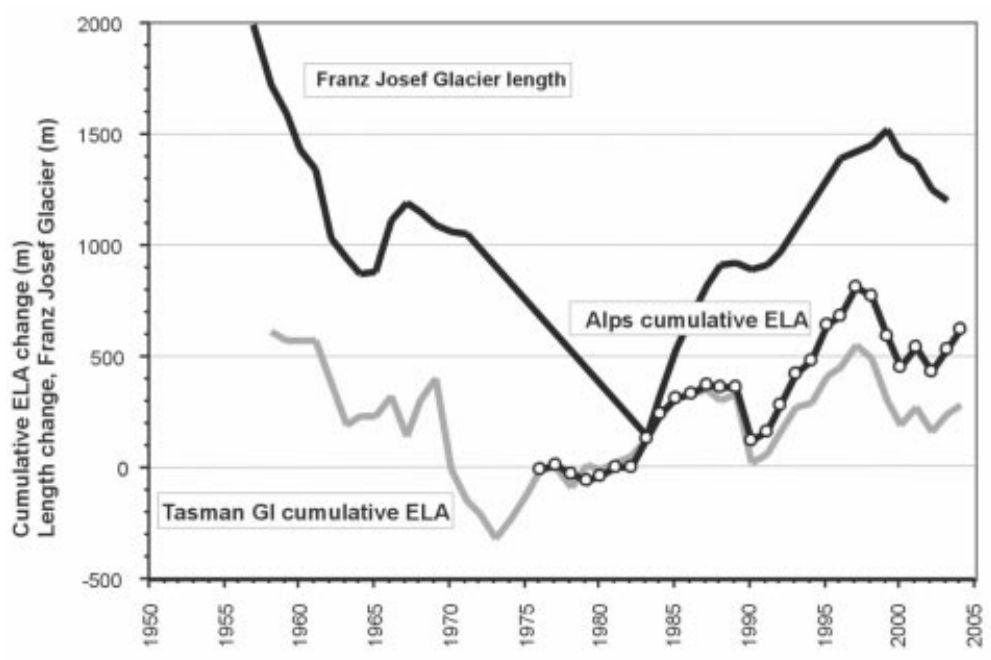

2; Chinn 1995). This programme has continued since 1977 and has recorded the glacier changes throughout the recent period of positive balances. The ELA is used as a surrogate for mass balance measurements as worldwide mass balance measurements show a close relationship between the end-of-summer snowline altitude (ELA) and net mass balance with an $r^{2}$ of 0.8 (Chinn et al. in press). The data are gained from photographs taken from a light aircraft and at the same time data from other glaciers, including frontal positions, are also recorded (Chinn 1996).

The ELA readings are most convenient when presented as the negative of the departure from the long term, or equilibrium position, of the ELA. The resulting elevations, here termed the 'mass balance index' (MBI), are positive for positive mass balances (low snowlines) and negative for negative balances with high snowlines. The record of mean ELA changes for the Southern Alps used as proxy mass balance readings shows two periods of positive mass balances from 1980 to 1987 and from 1991 to 1997 (Fig. 5). These are mean 'index' glacier values that indicate the trend of annual mass balance changes throughout the Southern Alps. The positive balance trend years are readily apparent when these values are plotted as the percentage of glaciers having positive balances each year (Fig. 5).

No frontal advances or positive mass balances were apparent when the ELA monitoring commenced in 1977, and the change to positive mass balances only became apparent when the first of the very responsive glaciers like the Franz Josef and Fox began to thicken and advance in 1983/84 and $1985 / 86$ respectively. The mean ELA record is compared with the frontal fluctuations of the Franz Josef Glacier and the longer Tasman Glacier ELA record in Fig. 6. The Tasman Glacier ELA record is reasonably representative of the Southern Alps as it has a correlation coefficient $r^{2}$ of 0.808 with the mean 'index' ELAs for the Southern Alps (Chinn and Salinger 2002).

The index glacier ELA record of Fig. 6 shows a sharp rise to positive balances commencing in 1983, with a period of zero to negative balances from 1987 to 1990 . Positive balances continued until 1997 and the mass gain to the glaciers over this period was quite significant. The most spectacular of all of the advances at the Franz Josef Glacier regained $1200 \mathrm{~m}$ from 1984 to 2000, an extension which recovered a significant $41 \%$ of length lost since 1900. The expansion thickened the trunks of the large valley glaciers sufficiently for the pulse to be visible on some glaciers as surface ice bulges. On the Hooker and Grey Glaciers the advance overwhelmed the proglacial lake growth and minor readvances were detected (Kirkbride and Warren 1997; T. Chinn, pers. obs). Associated with the positive balance period, there has been a mean lowering of the snowline by $67 \mathrm{~m}$ since the 1970s (Chinn 1999). Using an average lapse rate of $0.7^{\circ} \mathrm{C}$ per 100 $\mathrm{m}$, the downward shift represents a general cooling of $0.47^{\circ} \mathrm{C}$ since the late 1970 s assuming precipita- 


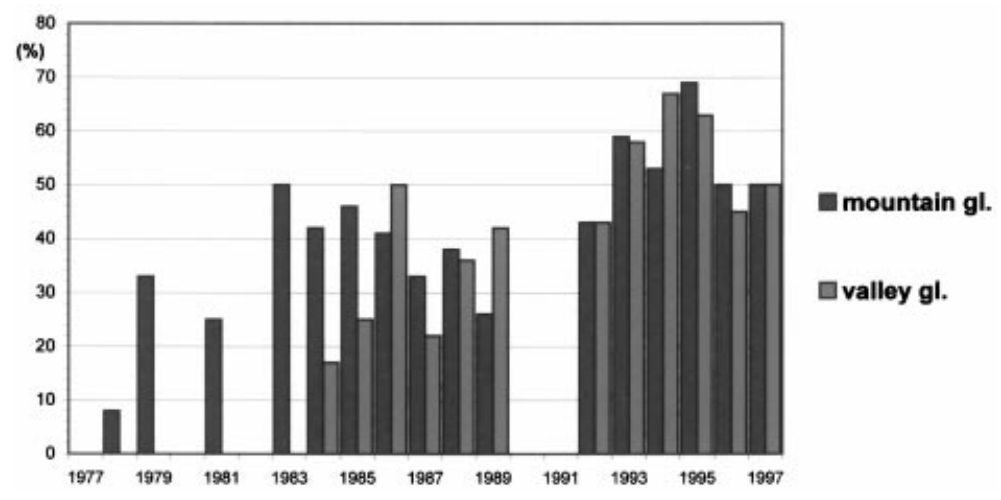

Fig. 7. Percentage of 38 New Zealand mountain glaciers and 26 valley glaciers advancing (data source: Chinn 1996)

tion constant. If temperature remained constant then, using the relationships of Ohmura et al. (1992), this 67 m ELA depression represents a precipitation increase of $350 \mathrm{~mm}$.

The index glacier ELA record suggests that the positive balances commenced in 1983, at the same time that the readvance commenced on the fast response glaciers. However when response times are considered, these glaciers indicate that the change occurred at least 5 years earlier, before 1978. The Tasman Glacier ELA record shows a more subtle period of positive balances commencing in 1974, which gives an appropriate time for the first observed responses of 1983/84. The 1983/84 readvance of the Franz Josef Glacier, which has a response time of 5 to 7 years (Hooker and Fitzharris 1999), indicates that the balance change occurred some time in the period 1976 to 1979. All of these indicators coincide with a change in phase of the Interdecadal Pacific Oscillation (IPO) (discussed below) which occurred in 1976/77 and continued until 1998.

In an attempt to isolate the year when the first effective change to positive mass balances occurred, the frontal positions of 111 glaciers opportunistically monitored on the snowline surveys, were scrutinized for the year when a first readvance could be recognized. The results show that there were a few early expansions from 1978, followed by a widespread advance commencing in 1983. By assuming a minimum response time of about 5 years for the most responsive mountain glaciers (Fig. 7) the change to dominantly positive balances was indicated to be in $1976 / 77$. Prior to this time, the nearest recorded advance was a minor event in 1966-1967 on Franz Josef Glacier. The valley glaciers showed a similar pattern (Fig. 7) but a lower proportion were advancing because of the longer response times of these glaciers.

\section{Causes of the recent glacier expansion Norway}

Analysis of meteorological data series from Bergen, which is representative of the maritime glaciers, shows that the positive net balance for the maritime glaciers of southern Norway is related to increased winter precipitation and snow accumulation (Liestøl 1967; Hurrel 1995; Winkler et al. 1997; Nesje et al. 2000). An increase in winter precipitation is among the most significant of the climatic trends in the maritime regions of southern Norway (Førland et al. 1992). The years 19711976 and 1989-1995 had well above average snow accumulation. A comparable increase in winter precipitation and glacier mass gain also occurred in the southern areas of northern Norway (e.g. Svartisen, Okstindan), excluding the far north (Haakensen 1989).

Not only has the annual precipitation and the precipitation during the accumulation season increased, but in addition, the timing of the precipitation maximum has shifted from autumn into winter in the 1990s compared to the 1980s (Fig. 8). Autumn, especially September and October, is usually a very changeable period of the year with temperatures decreasing by nearly $1^{\circ} \mathrm{C}$ per week (O. Liestøl, pers.comm.) accompanied by high precipitation. The later in the accumulation season the precipitation maximum occurs, the higher is the proportion of snow to rain lower on the glaciers. Rain is normally the dominant form of precipitation on low elevation glaciers well into the late autumn. The changes in monthly precipitation moni- 
Fig. 8. Upper panel: precipitation at Bergen (cf. Fig. 1) during the accumulation season (OctoberApril). Data not corrected for the breaks in homogeneity of 1903/04 and 1984/85 due to location shifts of the meteorological station. Mean winter precipitation increased by $360 \mathrm{~mm}(c .33 \%)$ during the period. Solid line is 5-year running mean, and the stippled line the linear trend over the whole period.

Centre panel: air temperature at Bergen during glacier ablation season (May-September). Mean summer temperature has increased by about $0.6^{\circ} \mathrm{C}$ since 1860 . Solid line and stippled line as above.

Lower panel: comparison of monthly precipitation at Bergen during the periods 1977/78-1987/ 88 and 1988/89-1998/99. The season with highest precipitation has moved from autumn to the middle of winter (data source: Det Norske Meteorologiske Institutt (DNMI))
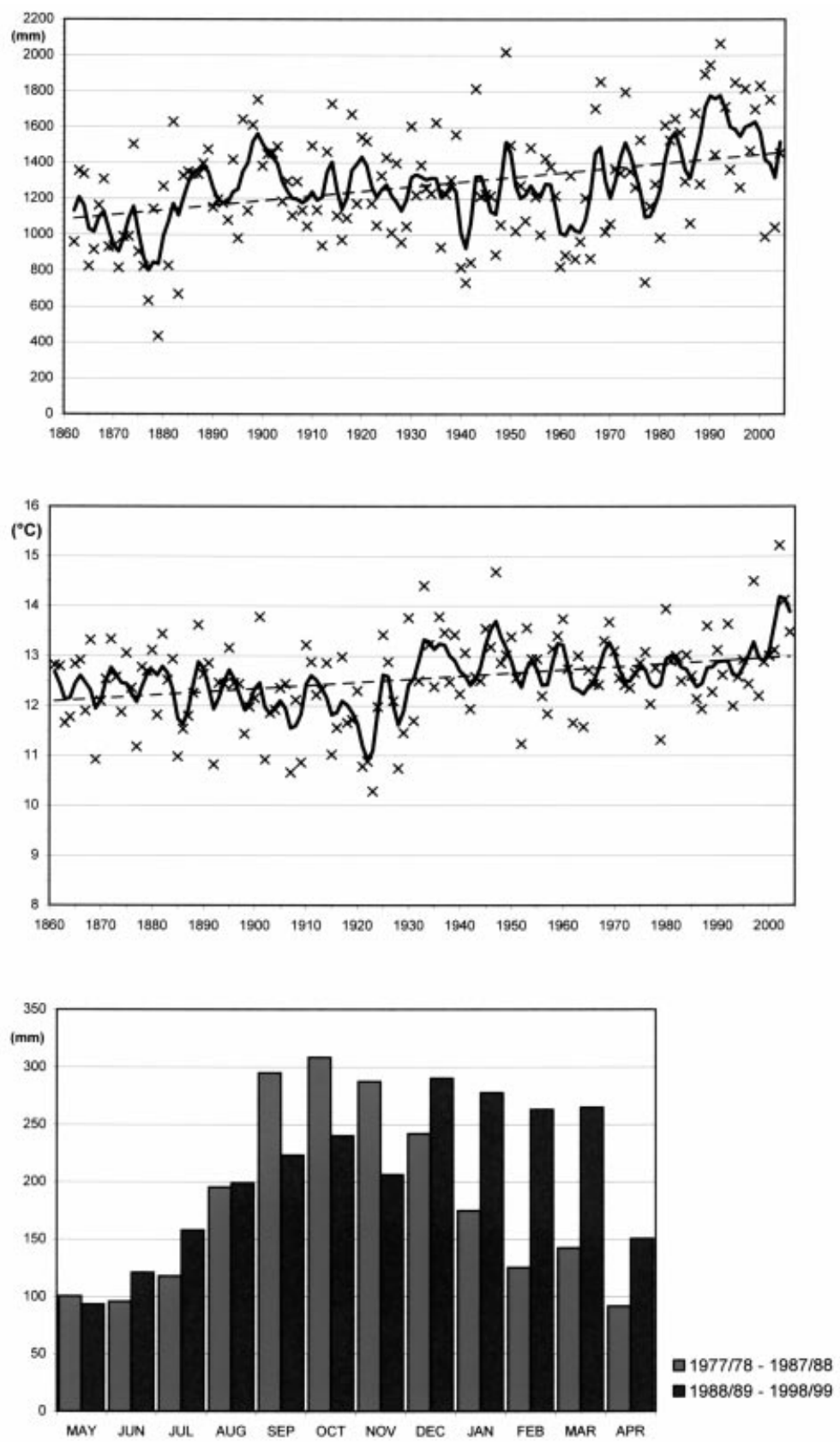

tored after 1988/89 support the overall increase in winter precipitation during the period. The rapid increase in net balances since 1988/89 cannot be explained by total precipitation changes alone. The sensitivity of maritime glaciers to a combination of temperature and precipitation changes in autumn has been shown by modelling (Laumann and Reeh 1993; Jóhannesson et al. 1995). This seasonal sensitivity of the maritime glaciers and the key role of autumn climate could also be used to interpret 
Holocene glacier chronologies (e.g. Nesje et al. 1991). An autumn increase in air temperature combined with an early (summer) precipitation maximum has a very strong negative effect on glacier mass balance, as not only does the ablation season last longer but there is also lower net accumulation as well. The summer air temperature increase required to explain the collapse of the glaciers in maritime southern Norway during the Middle Holocene is much higher than the increase required in autumn accompanied by a shift of the precipitation maximum (apart from the negative effect of a drop in annual precipitation).

Summer temperatures of recent decades show no significant variations, apart from the very recent warm summers at the beginning of the 21 st century (Fig. 8). A significant increase in winter temperatures of about $1.2^{\circ} \mathrm{C}$ during the past 140 years measured for Bergen, and assumed representative of the region. (Winkler 2001) corresponds well with the increase in winter precipitation, as mild and wet winters are associated with frequent moist southwesterly airflow and high cyclonic activity (high zonal index). A frequent cyclone track enters Norway at Stadlandet and following the Norwegian coast northward toward Lofoten, a situation that delivers storm precipitation to the maritime glaciers of both southern and northern Norway south of Lofoten. The northernmost glaciers in Norway receive most of their accumulation from the northwest. This circulation and similar circulation patterns responsible for high winter balances and resulting positive net balances in the maritime part of Scandinavia have a significant correlation with the North Atlantic Oscillation (NAO). The NAO is an index of strength of westerly circulation in winter over western Europe, measured by the pressure gradient between Stykkisholmur in Iceland and Punta Delgada in Azores (Rogers 1984; Lamb and Peppler 1987). This index shows a strengthened winter westerly circulation over the North Atlantic since the 1980s. Correlations between atmospheric circulation and winter balances at the most maritime glaciers have been demonstrated by Pohjola and Rogers (1997) and Nesje et al. (2000). In particular the highly positive NAO of 1988/89 (Hurrel 1995) corresponds well with the period of glacier mass increase in the maritime parts of Scandinavia and has contributed to the recent winter warming. Two minor periods of high positive NAO index correspond well to the two readvances during the first half of the 20th century at Jostedalsbreen.
According to Pohjola and Rogers (1997), maritime circulation in both summer and winter shows a good correlation with glacier mass balances. High pressure over the Barents Sea seems to be a critical factor in the summer. Pohjola and Rogers (1997) introduce a Norwegian Sea Index (NSI, i.e. the pressure gradient between Vardø in northern Norway and Valentia in Ireland) which, due to its more local character, gives a better correlation with glacier mass balance than does the NAO, especially in northern Norway. A correlation between the NAO and glacier mass balance in maritime western Scandinavia can be detected in the data provided by Appenzeller et al. (1998) from Greenland ice cores. These show strong positive NAO anomalies between AD 1690 and 1720, which are in phase with the LIA advance in Scandinavia, while the reconstructed winter-only NAO of Cook et al. (1999) does not correlate very well with the Greenland data.

\section{New Zealand}

Numerous studies have been made to relate glacier fluctuations to meteorological variables, mainly on one glacier, the Franz Josef, and usually employing only temperature and precipitation (e.g. Suggate 1950; Soons 1971; Hessell 1980) as these were the only meteorological variables with long time series available. These temperature and precipitation correlation studies have accounted for about $80 \%$ of the glacier variance (Salinger et al. 1983). Temperature changes may be more important than precipitation as Oerlemans (1997) found for the climate sensitivity of the Franz Josef Glacier that a $30 \%$ increase in precipitation would be required to compensate for a $1{ }^{\circ} \mathrm{C}$ warming. Further, Kuhn (1979) calculated from measurements made in Ötztal (Austrian Alps) that a $100 \mathrm{~m}$ change in ELA requires variations in winter accumulation of 400 $\mathrm{mm}$ water equivalent (w.e.), in summer free air temperature of $0.8^{\circ} \mathrm{C}$, or in mean summer radiation balance of $15.05 \mathrm{~W} \mathrm{~m}^{-2}$ for alpine glaciers. Similarly, the equivalent values for temperature precipitation and radiation at the ELA calculated by Ohmura et al. (1992) using data obtained for 70 glaciers from different parts of the world found that a $100 \mathrm{~m}$ change in ELA is approximately equivalent to $538 \mathrm{~mm}$ w.e. change, or a $1{ }^{\circ} \mathrm{C}$ temperature change, or a net radiation change of $7 \mathrm{~W} \mathrm{~m}^{-2}$.

Correlations of the Franz Josef Glacier frontal fluctuations and climate using only temperature and precipitation were inconclusive (Suggate 
1950; Soons 1971; Hessell 1980; Salinger 1982) and sparked a lively debate on the principal causes of the glacier's behaviour. In a summary, Hessell (1983) concluded that there had been no general temperature increase over the period of glacier retreat. In a study of the fluctuations of the nearby Stocking Glacier, Salinger et al. (1983) used a principal component regression analysis with temperature lagged by 2 years and precipitation lagged by 5 years. This study found that temperature is the more important variable and their model explained $83 \%$ and $71 \%$ of terminus variation. A significant relationship was found between temperature and retreat, but the relationship between precipitation and fluctuations was not as clear.

Again on the Franz Josef Glacier, Hooker and Fitzharris (1999) made a comparison of two 20year periods of retreat (1954-1974) and advance (1974-1994) phases with the data separated into accumulation (April-October) and ablation (November-March) seasons. The ablation season has been about $0.2^{\circ} \mathrm{C}$ cooler during the advance than the retreat phase, but there is no significant difference in accumulation season temperatures. There were, however, significant precipitation changes between the retreat and advance phases. In a location receiving nearly $10000 \mathrm{~mm} \mathrm{a}^{-1}$, the advance phase received an average of $686 \mathrm{~mm}$ more in the ablation season and $453 \mathrm{~mm}$ more in the accumulation season.

One of the more promising approaches to climate-glacier studies is to relate glacier fluctuations with atmospheric circulation patterns on a regional scale. The use of atmospheric circulation has two advantages over correlations with meteorological variables. Firstly circulation includes the influences of all weather factors affecting glacier balance in addition to temperature and precipitation, and secondly it permits decadal-scale glacier fluctuations to be related to hemispherical and global climate oscillations. The El Niño/Southern Oscillation (ENSO) strongly influences circulation over New Zealand (Mullan 1995). El Niño seasons are characterized by generally strengthened westerly circulation in summer, southerly circulation in winter and southwesterly circulation in autumn and spring with lower than normal temperatures. La Niña seasons show the opposite circulation and temperature anomalies, with weakened westerly circulation in summer, and southwesterly circulation in autumn and spring, and strengthened northerly circulation in winter. ENSO has a 2 to 8 year cycle. The Interdecadal Pacific Oscillation (IPO), however, is a feature that operates on decadal time scales. The positive phase is characterized by stronger, and the negative phase by weaker westerly circulation over the South Island (Salinger et al. 2001).

Examination of the links between climate and glacier change using atmospheric circulation initiated by Fitzharris et al. (1997) showed that largescale circulation patterns exert a strong control on glacier balance through their teleconnections with precipitation and temperature. On their Franz Josef Glacier study for the ablation season, Hooker and Fitzharris (1999) found no difference in the strength of westerly winds between the retreat and advance phases, but in the accumulation seasons there was a marked increase in the strength of the westerlies. In the advance phase the ENSO index was predominantly negative, whereas in retreat phase it was slightly positive indicating a La Niña tendency. Sea level pressure anomalies during the retreat phase were above normal over New Zealand with more anticyclones to the southeast of the country. Conversely during the advance phase, pressures were lower than normal with more anticyclones centred to the south of Australia. Thus the change from retreat to advance phase is associated with a westward shift in the location of the positive sea level pressure anomalies of about $55^{\circ}$ of longitude approximately along the $45^{\circ} \mathrm{S}$ parallel. The advance period is associated with cool sea surface temperature anomalies near New Zealand and warm anomalies in the eastern equatorial region of the Pacific Ocean (Clare et al. 2002).

Hooker and Fitzharris (1999) concluded that during the period of glacier expansion the atmospheric circulation pattern favours higher accumulation as well as reduced ablation. The Southern Hemisphere westerly wind belt was further north in the New Zealand region. There were anomalous southwesterly winds over the country, especially during the accumulation season. Stronger westerlies generate higher precipitation and melt is retarded because of cooler temperatures and increased cloudiness (Hay and Fitzharris 1988). Increased albedo from more frequent summer snowfalls also limits melt (Fitzharris et al. 1992). Atmospheric circulation during periods of glacier retreat favoured both lower accumulation and increased ablation losses.

Glacier mass changes from the ELA record show good relationships with the ENSO and the IPO changes in atmospheric circulation. Positive mass balances and advances are associated with strengthened west to southwest circulation. Nega- 
Table 4. Climatological and circulation patterns influencing the mass balance of New Zealand glaciers (after Clare et al. 2002; Hooker and Fitzharris 1999)

\begin{tabular}{lll}
\hline & $\begin{array}{l}\text { Positive net balance } \\
\text { Low snowline } \\
\text { Glacier advance }\end{array}$ & $\begin{array}{l}\text { Negative net balance } \\
\text { High snowline } \\
\text { Glacier retreat }\end{array}$ \\
\hline Wind direction anomaly & southerly & northerly \\
Westerly air flow over the Southern Alps & stronger & negative \\
$700 \mathrm{hPa}$ geopotential anomalies to the southeast of New Zealand & positive \\
$700 \mathrm{hPa}$ geopotential anomalies in the southeast Pacific & stronger & negative \\
Sub-tropical jet stream & cool & weaker \\
Sea surface temperature anomalies near New Zealand & warm & warm \\
Sea surface temperature anomalies towards equatorial South America & increased & cool \\
Precipitation & lower & decreased \\
Air temperature during ablation season & stronger & higher \\
Westerly air flow during ablation season & northwards & weaker \\
Position of main westerly zone & northwards & southwards \\
Position of the sub-tropical high pressure zone & southwesterly & southwards \\
Air flow anomalies during ablation season & negative & positive \\
Pressure anomaly over new Zealand in ablation season & negative & positive \\
Southern Oscillation Index (SOI) & El Niño & La Niña \\
Circulation phase & & \\
\hline
\end{tabular}

tive mass balances and retreats are associated with higher than normal summer pressures over the New Zealand region (Table 4) and weakened west to southwest circulation.

The New Zealand period of glacial expansion relates very well to a change to the positive phase of the IPO from 1977 to 1998, and a period of climate with frequent El Niño events. As a result of the strengthened westerly and southwesterly circulation, South Island west coast and Southern Alps precipitation increased by $10-15 \%$ (Salinger and Mullan 1999).

\section{Discussion}

While the majority of glaciers worldwide are retreating, the maritime glaciers of Norway and New Zealand are among the few examples of glacier expansion in the late 20th century. Glaciers of both regions are situated in maritime climates in the belts of strong westerly circulation. An increase in the strength of this circulation and an associated increase in precipitation together with lower air temperatures during the ablation seasons are the climatic variations responsible for the mass balance increase in both regions. However, mass balance increases can occur with little air temperature change or a slight increase if precipitation increases significantly.

One difference between the two regions is that seasonality seems to be more pronounced in Norway where precipitation has increased only during the accumulation seasons. Some high altitude glaciers like Jostedalsbreen could theoretically benefit from wet summer seasons with several snowfall events, but most other maritime glaciers have an elevation too low for this. The high-lying accumulation areas of New Zealand glaciers have also benefited from increased precipitation during the summer as most of this precipitation will fall as snow. Compared to Norway, air temperatures at the New Zealand glacier tongues are higher both in winter and summer and ablation will be higher. Very high precipitation makes mass turnover at the New Zealand glaciers higher than that of Norway and the mass balances of the glaciers will therefore be even more sensitive to fluctuations of the climate with enhanced amplitude of subsequent terminus position changes. In addition, the higher the mass turnover, the greater the effect that variations of single meteorological variables (e.g. summer air temperature, winter precipitation) will have on the glacier net balance. Compared to glaciers in continental regions (e.g. the European Alps), the glaciers of both regions are therefore much more climate sensitive. In both regions, the first decades of the 20th century showed no pronounced glacier retreat, with some stationary or even readvancing glacier fronts. The middle of the 20th century was, as in many other glacier regions, a period of spectacular retreat as 
the glaciers responded to climate warming that occurred since the end of the cooler 19th century. The recent glacier advances in both countries were more extensive than any others since this cooler period, a pattern that is much more obvious in Norway than in New Zealand. Around the year 2000, the advances of the more responsive glaciers ceased in both countries. In Norway, this may be a temporary halt as the glaciers with longer response times continue to advance and mass balance measurements continue to be mainly positive, suggesting at least some ongoing advances during the next few years. In New Zealand, ELA values indicate that after 2000 balances have settled to near equilibrium values (Fig. 6).

One difference between the two regions is that a comparable west-east gradient of different extents of advance is clearly visible in Norway but did not occur in New Zealand. The ELA surveys show that the entire Southern Alps of New Zealand behave as a single entity responding to climate for glacier balance changes despite the large precipitation gradient (Lamont et al. 1999; Clare et al. 2002) and the observed widely different frontal behaviours are of course a product of differing response times, amounts of debris cover and proglacial lake effects.

In western Norway, positive mass balances and the subsequent glacier advances were caused by increased precipitation during the accumulation season and a shift of the precipitation maximum towards the winter when a greater fraction of the total will fall as snow. However, increased air and sea surface temperatures can instigate mild, wet winters with dominantly southwesterly air flow that can also increase glacier mass balance. Norway might be considered an example how 'global warming' can lead to glacier advance (provided that air temperatures do not exceed a critical threshold and are restricted to autumn). In New Zealand, the glacial advances occurred when strong westerly atmospheric circulation produced significantly increased precipitation over the Southern Alps (Salinger and Mullan 1999) despite small increases in regional surface air temperature.

\section{Conclusions}

Norway and New Zealand both lie in similar climatic zones dominated by humid maritime westerly wind circulation. Both countries experienced glacial advances, more extensive than any other since the end of the 19th century cool period, which commenced in the early 1980 s and ceased around 2000. Glacier mass balance data associated with these advances were gained from balance studies in Norway and from ELA records in New Zealand. Common to both countries, the positive glacier balances are associated with increases in the strength of westerly atmospheric circulation which lowered ablation season temperatures in Norway and increased precipitation to the glaciers in both countries. In New Zealand the period of increased mass balance was coincident with a change in the IPO and an associated increase in ENSO events. The positive balances occurred as a nearly spatially uniform increase throughout the Southern Alps. In Norway the advances are linked to a strongly positive NAO which caused a seasonal precipitation shift to an increase in the accumulation season and a shift of maximum precipitation towards the end of the ablation season. The positive balances also occurred in a strong west-east gradient with no balance increases to the continental glaciers of Scandinavia.

The positive balances show that glacial expansion can occur when atmospheric circulation changes to produce a marked increase in precipitation even with small increases of surface air temperature. Maritime temperate glaciers are thus very sensitive to changes in atmospheric circulation.

\section{Acknowledgements}

The New Zealand section of this work was carried out with the National Institute of Water and Atmospheric Research Ltd under contract No. CO1X0202 of the New Zealand Foundation for Research, Science and Technology. Part of this work carried by S.Winkler was supported by a personal grant (contract WI 1701/1) of the Deutsche Forschungsgemeinschaft (DFG).

\section{T. Chinn, 20 Muir Road, Lake Hawea, RD2 Wana- ka, Otago, New Zealand.}

\section{S. Winkler, Department of Geography, University of Würzburg, 97074, Würzburg, Germany}

M.J. Salinger, national institute of water and athmospheric Research, Box 109-695, Auckland, New Zealand

N. Haakensen, Norwegian Water Resources and Energy Directorate (NVE), PB. 5091 Majorstua, N-0301 Oslo, Norway 


\section{References}

Anderson, B., 2003: The response of Franz Josef Glacier to climate change. $\mathrm{PhD}$ thesis. University of Canterbury. Christchurch. 129 p.

Anderton, P.W. and Chinn, T.J., 1978: Ivory Glacier, New Zealand, an I.H.D. representative basin study. Journal of Glaciology, 20: 67-84.

Appenzeller, C., Stocker, T.F. and Anklin, M., 1998: North Atlantic Oscillation dynamics recorded in Greenland ice cores. Science, 282: 446-449.

Ballantyne, C.K., 1990: The Holocene glacial history of Lyngshalvöya, northern Norway: chronology and climatic implications. Boreas, 19: 93-117.

Bickerton, R.W. and Matthews, J.A., 1993: Variations of outlet glaciers from the Jostedalsbreen ice-cap, southern Norway: a regional lichenometric-dating study of ice-marginal moraine sequences and their climatic significance. Journal of Quaternary Science, 8: 45-66.

Bogen, J., Wold, B. and Østrem, G., 1989: Historic glacier variations in Scandinavia. In: Oerlemans, J. (ed.): Glacier Fluctuations and Climatic Change. Reidel. Dordrecht. 109-128.

Chinn, T.J.H., 1995: Glacier fluctuations in the Southern Alps of New Zealand determined from snowline elevation. Arctic and Alpine Research, 27: 187-198.

Chinn, T.J.H., 1996: New Zealand glacier responses to climate change of the past century. New Zealand Journal of Geology and Geophysics, 39: 415-428.

Chinn, T.J.H., 1999: New Zealand glacier response to climate change of the past 2 decades. Global and Planetary Change, 22: $155-168$

Chinn, T.J.H., 2001: Distribution of the glacial water resources of New Zealand. Journal of Hydrology (NZ), 40(2): 139-187.

Chinn, T.J.H. and Salinger, M.J., 2002: New Zealand glacier snowline survey, 2002. NIWA Technical Report.

Chinn, T.J.,Heydenrych, C. and Salinger, M.J., (in press): Use of the ELA as a practical method of monitoring glacier response to climate in the New Zealand's Southern Alps. Journal of Glaciology.

Clare, G.R., Fitzharris, B.B., Chinn, T.J.H. and Salinger, M.J. 2002: Variation in end-of-summer snowlines of the Southern Alps of New Zealand, and relationships with Southern Hemisphere atmospheric circulation and sea surface temperature patterns. International Journal of Climate, 22: 107-120.

Cook, E.R., D'Arrigo, R.D. and Briffa, K.R., 1999: A reconstruction of the North Atlantic Oscillation using tree-ring chronologies from North America and Europe. The Holocene, 8: 917.

Dowdeswell, J.A., Hagen, J.O., Bjфrnsson, H., Glazovsky, A.F., Harrison, W.D., Holmlund, P., Jania, J., Koerner, R.M., Lefauconnier, B., Ommanney, C.S.L. and Thomas, R.H., 1997: The mass balance of circum-Arctic glaciers and recent climate change. Quaternary Research, 48: 1-14.

Erikstad, L. and Sollid, J.L., 1986: Neoglaciation in South Norway using lichenometric methods. Norsk Geografisk Tidskrift, 40: 85-100.

Fagri, K., 1934: Über die Längenvariationen einiger Gletscher des Jostedalsbre und die dadurch bedingten Pflanzensukzessionen. Bergens Museums Årbok 1933 Naturvidenskapelig rekke 7: 255 .

Fagri, K., 1948: Brevariasjoner i Vestnorge i de siste 200 år. Naturen, 72: 230-243.

Fitzharris, B.B., Hay., J.E. and Jones, P.D., 1992: Behaviour of New Zealand glaciers and atmospheric circulation changes over the past 130 years. The Holocene, 2: 97-106.
Fitzharris, B.B., Chinn, T.J.H. and Lamont, G.N., 1997: Glacier balance fluctuations and atmospheric circulation patterns over the Southern Alps, New Zealand. International Journal of Climate, 17: 745-763.

Førland, E.J., 1993: Nedbørnormaler normalperiode 1961-1990. DNMI Rapport 39/93 Klima. 63 p.

Førland, E.J., Hanssen-Bauer, I. and Nordli, P.Ø., 1992: New Norwegian climate normals - but has the climate changed? Norsk Geografisk Tidskrift, 46: 83-94.

Gellatly, A.F., 1985: Historical records of glacier fluctuations in Mt Cook National Park, New Zealand: a century of change. Geographical Journal, 151: 86-99.

Gellatly, A.F., Chinn, T.J.H. and Röthlisberger, F., 1988: Holocene glacier variations in New Zealand: a review. Quaternary Science Reviews, 7: 227-242.

Griffey, N.J. and Worsley, P., 1978: The pattern of Neoglacial glacier variations in the Okstindan region of northern Norway during the last three millennia. Boreas, 7: 1-17.

Griffiths, G.A. and McSaveney, M.J., 1983: Distribution of mean annual precipitation across some steep-land regions of New Zealand. New Zealand Journal of Science, 26: 197-209.

Grove, J.M., 1988: The Little Ice Age. Routledge. London and New York. 498 p.

Haakensen, N., 1989: Akkumulasjon på breene i Norge vinteren 1988-89. Varet, 13: 91-94.

Haeberli, W. and Hoelzle, M., 1995: Application of inventory data for estimating characteristics of and regional climate-change effects on mountain glaciers: a pilot study with the European Alps. Annals of Glaciology, 21: 206-212.

Haeberli, W., Frauenfelder, R., Hoelzle, M. and Maisch, M., 1999: On rates and acceleration trends of global glacier mass changes. Geografiska Annaler, 81A: 585-591.

Hay, J.E. and Fitzharris, B.B., 1988: The synoptic climatology of ablation on a New Zealand glacier. International Journal of Climate, 8: 201-215.

Hessell, J.W.D., 1980: Apparent trends of mean temperature in New Zealand since 1930. New Zealand Journal of Science, 23: 1-9.

Hessell, J.W.D., 1983: Climatic effects on the recession of the Franz Josef Glacier. New Zealand Journal of Science, 26: 315-320.

Hoel, A. and Werenskiold, W., 1962: Glaciers and snowfields in Norway. Norsk Polarinstitutt Skrifter, 114, 291 p.

Hooker, B.L. and Fitzharris, B.B., 1999: The correlation between climatic parameters and the retreat and advance of Franz Josef Glacier, New Zealand. Global and Planetary Change, 22: 3948.

Hurrel, J.W., 1995: Decadal trends in the North Atlantic Oscillation: regional temperatures and precipitations. Science, 269: 676-679.

IPCC, 2001: Climate Change 2001: The Scientific Basis. Contribution of Working Group I to the Third Assessment Report of the Intergovernmental Panel on Climate Change. In: Houghton, J.T., Ding, Y., Griggs, D.J., Noguer, M., van der Linden, P.J., Dai, X., Maskell, K., and Johnson, C.A. (eds): Cambridge University Press. Cambridge. 881 p.

Jóhannesson, T., Sigurðsson, O., Laumann, T. and Kennett, M., 1995: Degree-day glacier mass-balance modelling with applications to glaciers in Iceland, Norway and Greenland. Journal of Glaciology, 41: 345-358.

Karlén, W., 1979: Glacier variations in the Svartisen area, Northern Norway. Geografiska Annaler, 61A: 11-28.

Kirkbride, M., 1993: The temporal significance of transitions from melting to calving termini at glaciers in the central Southern Alps of New Zealand. The Holocene, 3: 232-240.

Kirkbride, M.P. and Warren, C.R., 1997: Calving processes at a 
grounded ice cliff. Annals of Glaciology, 24: 116-121.

Kjøllmoen, B., 2000: Glasiologiske undersøkelser i Norge 1999. NVE Rapport 2000/2. 140 p.

Konnestad Sorteberg, H., 1998: Regional breovervåking i SørNorge. NVE Rapport 8/1998. 21 p.

Kuhn, M., 1979: On the computation of heat transfer coefficients from energy-balance gradients on a glacier. Journal of Glaciology, 22: 263-272.

Lamb, P.J. and Peppler, R.A., 1987: North Atlantic Oscillation: concept and an application. Bulletin of the American Meteorological Society, 68: 1218-1225.

Lamont, G.N., Chinn, T.J.H. and Fitzharris, B.B., 1999: Slopes of ELAs in the Southern Alps of New Zealand in relation to atmospheric circulation patterns. Global Planetary Change, 22: 209-219.

Laumann, T. and Reeh, N., 1993: Sensitivity to climate change of the mass balance of glaciers in southern Norway. Journal of Glaciology, 39: 656-665.

Lawrence, D.B. and Lawrence, E.G., 1965: Glacier studies in New Zealand. Mazama, 47: 17-27.

Liestøl, O., 1967: Storbreen glacier in Jotunheimen. Norsk Polarinstitutt Skrifter, 141, 63 p.

Matthews, J.A. and Shakesby, R.A., 1984: The status of the 'Little Ice Age' in southern Norway: relative-age dating of Neoglacial moraines with Schmidt hammer and lichenometry. Boreas, 13: 333-346.

Mullan, A.B., 1995: On the linearity and stability of Southern Oscillation-climate relationships for New Zealand. International Journal of Climate, 15: 1365-1386.

Nesje, A., 1989: Glacier-front variations at the outlet glaciers from Jostedalsbreen and climate in the Jostedalsbre region of western Norway in the period 1901-1980. Norsk Geografisk Tidskrift, 43: 3-17.

Nesje, A., Kvamme, M., Rye, N. and Lovlie, R., 1991: Holocene glacier and climate history of the Jostedalsbreen region, western Norway; evidence from lake sediments and terrestrial deposits. Quaternary Science Review, 10: 87-114.

Nesje, A., Lie, Ø. and Dahl, S.O., 2000: Is the North Atlantic Oscillation reflected in Scandinavian glacier mass balance records? Journal of Quaternary Science, 15: 587-601.

Oerlemans, J., 1989: On the response of valley glaciers to climate change. In: Oerlemans, J. (ed.): Glacier Fluctuations and Climate Change. Kluwer. Dordrecht. 353-371.

Oerlemans, J., 1994: Quantifying global warming from the retreat of glaciers. Science, 264: 243-245.

Oerlemans, J., 1997: Climate sensitivity of Franz Josef Glacier, New Zealand, as revealed by numerical modelling. Arctic and Alpine Research, 29: 233-239.

Ohmura, A., Kasser, P. and Funk, M., 1992: Climate at the equilibrium line of glaciers. Journal of Glaciology, 38: 397-411.

Østrem, G., Haakensen, N. and Melander, O., 1973: Atlas over breer i Nord-Skandinavia. NVE Meddelelser Hydrologisk Avdeling. 22. 315 p.

Østrem, G., Dale Selvig, K. and Tandberg, K., 1988: Atlas over breer i Sør-Norge. NVE Meddelelser Hydrologisk Avdeling. $61.247 \mathrm{p}$.

Paterson, W.S.B., 1994: The Physics of Glaciers. (third edition). Pergamon. Oxford. $380 \mathrm{p}$.

Pohjola, V.A. and Rogers, J.C., 1997: Atmospheric circulation and variations in Scandinavian glacier mass balance. Quaternary Research, 47: 29-36.

Porter, S.C., 2000: Onset of Neoglaciation in the southern hemi- sphere. Journal of Quaternary Science, 15: 395-408.

Rogers, J.C., 1984: The association between the North Atlantic Oscillation and the Southern Oscillation in the northern hemisphere. Monthly Weather Review, 112: 1999-2015.

Röthlisberger, F., 1986: 10000 Jahre Gletschergeschichte der Erde. Sauerländer. Aarau. 416 p.

Salinger, M.J., 1982: On the suggestion of post-1950 warming over New Zealand. New Zealand Journal of Science, 25: $77-$ 86.

Salinger, M.J. and Mullan, A.B., 1999: New Zealand climate: temperature and precipitation variations and their links with atmospheric circulation 1930-1994. International Journal of Climate, 19: 1049-1071.

Salinger, M.J., Heine, M.J. and Burrows, C.J., 1983: Variations of Stocking (Te Wae Wae) Glacier, Mount Cook, and climate relationships. New Zealand Journal of Science, 26: 321-338.

Salinger, M.J., Renwick, J.A. and Mullan, A.B., 2001: Interdecadal Pacific Oscillation and South Pacific climate. International Journal of Climate, 21: 1705-1721.

Soons, J.M., 1971: Recent changes in the Franz Josef Glacier. Proceedings, Sixth New Zealand Geography Conference. Christchurch. 195-200.

Suggate, R.P., 1950: Franz Josef and other glaciers of the Southern Alps, New Zealand. Journal of Glaciology 1: 422-429.

Tvede, A.M. and Liest $\phi l$, O., 1977: Blomsterskardbreen, Folgefonni, mass balance and recent fluctuations. Norsk Polarinstitutt Årbok, 1976: 225-234.

Wardle, P., 1973: Variations of the glaciers of Westland National Park and the Hooker Range, New Zealand. New Zealand Journal of Botany, 11: 349-388.

Winkler, S., 1996: Front variations of outlet glaciers from Jostedalsbreen, western Norway, during the twentieth century. Norges Geologiske Unders $\phi$ kelse Bulletin, 431: 33- 47.

Winkler, S., 2001: Untersuchungen zur Klima- und Morphodynamik in skandinavischen Gebirgsregionen während des Holozän-ein Vergleich ihrer Wechselwirkungen und Prozeßsysteme im überregionalen Kontext kaltgemäßigter maritimer Gebirgsregionen. Unpublished 'Habilitationsschrift'. University of Trier.

Winkler, S., 2003: A new interpretation of the date of the 'Little Ice Age' maximum at Svartisen and Okstindan, northern Norway. The Holocene, 13: 83-95.

Winkler, S., 2004: Lichenometric dating of the 'Little Ice Age' maximum in Mt.Cook National Park, Southern Alps, New Zealand. The Holocene, 14(6).

Winkler, $S$. (in press): The 'Schmidt hammer' as a relative-age dating technique: potential and limitations of its application on Holocene moraines in Mt Cook National Park, Southern Alps, New Zealand. New Zealand Journal of Geology and Geophysics, 48.

Winkler, S. and Haakensen, N., 1999: Kritische Überprüfung der Möglichkeit zur Prognose des Gletscherverhaltens auf Grundlage von Modellierungen - dargestellt anhand von regionalen Beispielen aus Norwegen. Petermanns Geographische Mitteilungen, 143: 291-304.

Winkler, S., Haakensen, N., Nesje, A. and Rye, N., 1997: Glaziale Dynamik in Westnorwegen - Ablauf und Ursachen des aktuellen Gletschervorstoßes am Jostedalsbreen. Petermanns Geographische Mitteilungen, 141: 43-63.

Manuscript received August 2004, revised and accepted December 2004. 